\title{
Construction of intimately coupled mesoporous Al2O3 nanosphere deposited 2D CdO with boosted charge separation, visible-light photocatalysis and bactericidal applications
}

Janani B

Bannari Amman Institute of Technology

S. Sudheer Khan ( $\sim$ ssudheerkhan@gmail.com )

Bannari Amman Institute of Technology https://orcid.org/0000-0002-9666-7672

\section{Research Article}

Keywords: Photocatalysis, CdO-Al203, Nanocomposites, Antibacterial activity

Posted Date: April 29th, 2021

DOI: https://doi.org/10.21203/rs.3.rs-439492/v2

License: (c) (i) This work is licensed under a Creative Commons Attribution 4.0 International License.

Read Full License 
Construction of intimately coupled mesoporous $\mathrm{Al}_{2} \mathrm{O}_{3}$ nanosphere deposited $2 \mathrm{D} \mathrm{CdO}$ with boosted charge separation, visible-light photocatalysis and bactericidal applications

B. Janani ${ }^{\mathrm{a}}$, S. Sudheer khan ${ }^{\mathrm{a}, *}$

${ }^{a}$ Nanobiotechnology Laboratory, Department of Biotechnology, Bannari Amman Institute of Technology, Sathyamangalam, Tamil Nadu, India.

${ }^{b}$ Department of Botany and Microbiology, College of Science, King Saud University, P.O. Box 2455 Riyadh 11451, Saudi Arabia.

*Corresponding author

S. Sudheer khan

Email: sudheerkhan@,bitsathy.ac.in

*Co-corresponding author

Asad syed 


\begin{abstract}
Pristine $\mathrm{Al}_{2} \mathrm{O}_{3}$ and $\mathrm{CdO}$ are known to possess poor photocatalytic activity individually. The formation of $\mathrm{CdO} / \mathrm{Al}_{2} \mathrm{O}_{3}$ heterojunction was investigated for the enhancement of photocatalytic performance. High resolution transmission electron microscopy (HRTEM), X-ray diffraction (XRD) and X-ray photoelectron spectroscopy (XPS) has been used to determine the crystalline feature and elemental composition of the NCs respectively . Peaks ascribed to Cd-O and O-Al-O was noted in fourier-transform infrared spectroscopy (FTIR) analysis. The NCs exhibits a high surface area $\left(27.23 \mathrm{~m}^{2} / \mathrm{g}\right)$ to their contributing particles which was analysed using BET analyser. The band gap energy of $\mathrm{CdO} / \mathrm{Al}_{2} \mathrm{O}_{3} \mathrm{NCs}$ was observed to be $2.95 \mathrm{eV}$ which shows a considerable energy shift from its individual particles, $\mathrm{CdO}(2.73 \mathrm{eV})$ and $\mathrm{Al}_{2} \mathrm{O}_{3}(3.94 \mathrm{eV})$. The results displayed that the degradation efficiency of the $\mathrm{CdO}-\mathrm{Al}_{2} \mathrm{O}_{3} \mathrm{NCs}$ was enhanced 14 times than pristine $\mathrm{Al}_{2} \mathrm{O}_{3}$ and 3.5 times than pristine $\mathrm{CdO}$. The $\mathrm{MB}$ dye has showed the half life period of 80 min. TOC analysis of degraded product supported high mineralization of the pollutants. The dye degradation was driven by $\mathrm{OH} \cdot$ radicals and the $\mathrm{CdO}-\mathrm{Al}_{2} \mathrm{O}_{3}$ nanocomposite possessed high reusability which was confirmed by six cycle test. Growth inhibition of E. coli, P. aeruginosa and B. subtilis was attained by exposure to $\mathrm{CdO} / \mathrm{Al}_{2} \mathrm{O}_{3} \mathrm{NCs}$. The $\mathrm{CdO}-\mathrm{Al}_{2} \mathrm{O}_{3} \mathrm{NCs}$ can be a viable solution for degradation of organic contaminants effectively under natural sun light as well as an efficient antibacterial agent.
\end{abstract}

Key words: Photocatalysis; $\mathrm{CdO}-\mathrm{Al}_{2} \mathrm{O}_{3}$; Nanocomposites; Antibacterial activity. 


\section{Introduction}

The growing industrialization and urbanization led to a disposal of diverse range of toxic pollutants to the environment [1]. One among of them is the complex dyestuffs, which are difficult to degrade due to their high chemical stability [2]. The urge for an innovation or an efficient modification has become vital one to sort out this environmental threat. Although the current wastewater treatment is applicable, the recently emerged advanced oxidation process (AOP) is far better as it is cost efficient $[3,4,5]$. The production of hydroxyl radicals upon exposure to the light source is the basic mechanism behind this light driven catalytic process. The fabrication of photocatalyst with the metal oxide semiconductors is quite appreciable as it enhances the oxidation effectively.

$\mathrm{Al}_{2} \mathrm{O}_{3}$ is an insulator oxide with a wide bandgap range reported in literatures over 3.4 - 9 $\mathrm{eV}$ [6-9]. It has taken a lot of attention as it has a high surface area with an orderly arrangement of the nanopore structures and a non-toxic cost effective compound with high thermal stability [10]. This orderly arrangement of nanopores makes it an excellent photocatalyst and its appreciable usage in the drug delivery, biosensors and electronic devices [11]. It has been explored that nanostructure has appreciable optical properties and finds its usage in the optoelectronic devices [12]. The method by which they are synthesized also has an effect over the photocatalytic activity. These nanostructures can be synthesized through sol-gel, thermal treatment and anodization. Among them, the anodization is the refined one to fabricate with reliability [13].

As a n-type semiconductor, $\mathrm{CdO}$ has a bandgap of $2.2-2.9 \mathrm{eV}$ [14]. It is a cost effective semiconductor with high electrical conductivity as it has shallow donors [15]. These shallow donors are offered by the oxygen vacancies and the cadmium atoms. It has been widely used in 
the photocatalytic applications and other electrochemical devices such as the supercapacitors. Though $\mathrm{CdO}$ is cheapest with high surface-volume ratio yet it is less preferred due to toxicity. The size and structure of the semiconductors has direct effect over the catalytic efficiency. They can be synthesized through chemical co-precipitation method as it is a reliable cost effective one which brings forth excellent homogeneity [16]. In the present study, $\mathrm{CdO}-\mathrm{Al}_{2} \mathrm{O}_{3}$ photocatalytic activity compared with pristine $\mathrm{CdO}$ and $\mathrm{Al}_{2} \mathrm{O}_{3}$. B. Subtilis, $P$. aeruginosa, E. coli and $S$. aureus has been used to evaluate the antibacterial activity of NCs.

\section{Materials and methods}

\subsection{Materials}

Staphylococcus aureus (MTCC 3160), E. coli (ATCC 14948), Pseudomonas aeruginosa (MTCC 1688), Bacillus subtilis (ATCC 11774) were procured from MTCC and ATCC. Methylene blue dye (Purity - 99\%), $\mathrm{Al}_{2}\left(\mathrm{SO}_{4}\right)_{3}, \mathrm{CdSO}_{4}$ and $\mathrm{CdSO}_{4}$ are marketed from Merck (Germany).

\subsection{Synthesis of CdO nanoparticles}

Chemical co-precipitation was exploited for synthesis of $\mathrm{CdO}$ with $0.1 \mathrm{M} \mathrm{CdSO}_{4}$ as the precursor. The precursor was dissolved in an aqueous solution and was homogenized under heat for a period of $30 \mathrm{~min}$. Then $25 \mathrm{~mL}$ of alkaline $\mathrm{NH}_{4} \mathrm{OH}$ was added up in a drop wise manner. Then the solution was vigorously heat stirred for $30 \mathrm{~min}$. The obtained precipitate has been centrifuged for $10 \mathrm{~min}$ at $10000 \mathrm{rpm}$. The pellets obtained after centrifugation were dried under hot air oven at $90{ }^{\circ} \mathrm{C}$ for $2 \mathrm{~h}$. The obtained $\mathrm{CdO}$ nanoparticle was calcinated at $500{ }^{\circ} \mathrm{C}$ for $1 \mathrm{~h}$.

\subsection{Synthesis of $\mathrm{CdO} / \mathrm{Al}_{2} \mathrm{O}_{3} \mathrm{NCs}$}

The synthesis of $\mathrm{CdO} / \mathrm{Al}_{2} \mathrm{O}_{3}$ nanocomposite involves sonication and thermal treatment. The calcinated $\mathrm{CdO}\left(0.1\right.$ M) was dispersed in $\mathrm{H}_{2} \mathrm{O}$ under sonication followed by addition of 
$\mathrm{Al}_{2}\left(\mathrm{SO}_{4}\right)_{3}(0.05 \mathrm{M})$ to the suspension. The mixture was then sonicated for $30 \mathrm{~min}$. The obtained solution was heat stirred for $30 \mathrm{~min}$ and $25 \mathrm{ml}$ of $\mathrm{NH}_{4} \mathrm{OH}$ was added to the solution alongside. The precipitate collected was centrifuged at $10000 \mathrm{rpm}$ for $10 \mathrm{~min}$ which was followed by water and ethanol wash. The collected NCs were calcinated for $1 \mathrm{~h}$ at $500{ }^{\circ} \mathrm{C} . \mathrm{Al}_{2} \mathrm{O}_{3}$ was prepared in a similar procedure as that of $\mathrm{CdO} / \mathrm{Al}_{2} \mathrm{O}_{3}$ without $\mathrm{CdO}$, followed by thermal treatment for $1 \mathrm{~h}$.

\subsection{Characterization of nanoparticles}

The elaborated details of instrumentations are provided in the supplementary material text S1.

\subsection{Photocatalysis experimental arrangement}

Photocatalytic efficiency of the NCs has been estimated based on the degradation of MB under visible light irradiation. The synthesized nanocomposite $(10 \mathrm{mg})$ was dispersed in $20 \mathrm{~mL}$ of the methylene blue dye $(25 \mathrm{mg} / \mathrm{L})$. The obtained solution was placed in dark to attain adsorption/desorption equilibrium. The setup was then shifted under $800 \mathrm{~W}$ halogen lamp until the absorbance decrease ceases. The degradation kinetics of the sample was studied for every 20 min. UV-spectrophotometer was used for the determination of MB degradation at 550-750 nm. The formulae given below was used for the calculation of percentage of degradation,

$\operatorname{Degradation}(\%)=\frac{A_{0}-A_{t}}{A_{0}} \times 100$

$\mathrm{A}_{0}-$ absorbance at initial time $(\mathrm{t}=0)$.

$\mathrm{A}_{\mathrm{t}}$ - absorbance at time $\mathrm{t}$.

\subsection{Reusability and scavenging}

The scavengers chosen for carrying out the experiment includes $1 \mathrm{mM}$ silver nitrate for oxidizing the electron radicals $\left(\mathrm{e}^{-}\right)$, benzoquinone for superoxide anion oxidation $\left(\mathrm{O}_{2}^{-}\right)$, isopropyl alcohol for the hydroxyl radical oxidation $(\mathrm{OH})$ and EDTA for hydrogen radical oxidation $\left(\mathrm{h}^{+}\right)$. The 
same protocol was followed to study photocatalytic effect of NCs under the presence of $1 \mathrm{~mL}$ of each scavenger separately. The leftover dye in the sample was quantified by recording the absorbance at $665 \mathrm{~nm}$. The scavenging efficiency was indicated based on the degradation percentage.

The reusability of the particles was checked to determine its efficient stability and practical use aside to the exhibited activity. The activity of NCs was tested in six successive photocatalytic cycles by MB dye degradation. During each cycle, the particles were collected, washed and employed for next set of runs by injecting fresh MB dye solution.

\subsection{Antimicrobial activity}

The bacterial species listed below were used to evaluate the antimicrobial activity of the NCs: $P$. aeruginosa, S. aureus, B. subtilis and E. coli. The species were cultured in LB broth for duration of 12-16 h, after which the bacterial cells were obtained upon centrifugation. Different concentrations of $\mathrm{CdO} / \mathrm{Al}_{2} \mathrm{O}_{3}(0.1,1,10$ and $100 \mathrm{mg} / \mathrm{L})$ were used for evaluation of antibacterial activity. Plate count method and dilution method were exploited to determine the viable cells count after $4 \mathrm{~h}$ of bacterial-NCs interaction.

\section{Results and discussion}

\subsection{Characterization}

\subsubsection{HRTEM, SAED and EDAX}

HRTEM analysis was performed to understand the structure and morphology of the $\mathrm{Al}_{2} \mathrm{O}_{3}$ loaded $\mathrm{CdO}$ along with the size range (Fig. 1a). The image depicts partially rough crystal structure. It can be observed as the $\mathrm{CdO}$ are hexagonal shaped nanoplates on which there is a semi-homologous distribution of $\mathrm{Al}_{2} \mathrm{O}_{3}$ on the surface. The $\mathrm{Al}_{2} \mathrm{O}_{3}$ grain appeared to be 
nanospherical in shape that looks almost uniform in size and distribution. The deposition of $\mathrm{Al}_{2} \mathrm{O}_{3}$ as appeared in HRTEM (fig. 1b) at $2 \mathrm{~nm}$ scale represents the attachment of highly crystalline $\mathrm{Al}_{2} \mathrm{O}_{3}$ nanospherical grains on $\mathrm{CdO}$ nanoplates. The uneven size of $\mathrm{CdO}$ nanoplates that result in porous channels will increase the number of active sites available for the surface reaction [M. Poloju et al., 2020]. This structure with high crystallinity, surface deposition and porous nature helps in both transmission of $\mathrm{e}^{-}$and diffusion of $\mathrm{O}_{2}$ gas and $\mathrm{H}_{2} \mathrm{O}$ to the reaction sites. This benefit the contact between charge carries, $\mathrm{O}_{2}$ and $\mathrm{H}_{2} \mathrm{O}$ and thus enhance the photocatalyst performance by the generation of ROS [X. Xing et al., 2019]. HRTEM image of $\mathrm{Al}_{2} \mathrm{O}_{3}$ and $\mathrm{CdO}$ with lattice fringes is shown in fig. 1b. Further the excellent crystallinity of the material will help in the long-term stability of the photocatalyst. The interplanar distance of 0.19 $\mathrm{nm}$ assigned to the (116) plane of $\mathrm{Al}_{2} \mathrm{O}_{3}$ and $0.23 \mathrm{~nm}$ assigned to the (102) plane of cubic $\mathrm{CdO}$. The deposition confirms the interface formation that resulted in $\mathrm{CdO} / \mathrm{Al}_{2} \mathrm{O}_{3}$ heterojunction. SAED analysis was done to determine the crystalline nature of NCs. The SAED indicates the presence of several concetarted diffraction rings. The result indicated the polycrystalline nature of the NCs as shown in Fig. 1a.

Supplementary material fig. S1a represents the SEM image of $\mathrm{CdO} / \mathrm{Al}_{2} \mathrm{O}_{3} \mathrm{NCs}$. The SEM images of $\mathrm{CdO}$ and $\mathrm{Al}_{2} \mathrm{O}_{3}$ was represented in supplementary material fig. S1b and c that represents the porous (dark black spots) morphology of prepared NCs. The EDAX profiles of $\mathrm{CdO} / \mathrm{Al}_{2} \mathrm{O}_{3}$ showed three peaks corresponding to cadmium, aluminium and oxygen.

\subsubsection{XRD}

XRD was used to clarify the crystal phase of $\mathrm{CdO} / \mathrm{Al}_{2} \mathrm{O}_{3}$ and the XRD patterns of pristine $\mathrm{Al}_{2} \mathrm{O}_{3}, \mathrm{CdO}$ and the NCs CdO- $\mathrm{Al}_{2} \mathrm{O}_{3}$ was represented in Fig. 1d. The XRD patterns of pure $\mathrm{CdO}$ fitted well with the crystal structure of hexagonal with space group: P63mc (186) with respect to 
$2 \theta$ positions and intensity (JCPDS card no. 01-076-8931). The XRD pattern of CdO with peaks at $2 \theta$ value of $29.4,35.1,48.9,52.0,56.0,64.4,67.0$, and $74.3^{\circ}$ were indexed to (100), (101), (110), (102), (103), (004), (202) and (104) respectively. In the hexagonal CdO structure, there is a close packing crystal structure with respect to P63mc space group, where the anions are located at the six-coordination sites, while the cations fill half of the four-coordinated sites [B. H. Park 2020].

The XRD patterns of pure $\mathrm{Al}_{2} \mathrm{O}_{3}$ fitted well with the crystal structure in space group: Pm3m with respect to $2 \theta$ positions and intensity (JCPDS card no. 00-011-0661). The presence of $\mathrm{Al}_{2} \mathrm{O}_{3}$ was inferred from the peaks spotted at the $2 \theta$ value of $22.6,25.2,28.8,37.4,38.6,45.9$, 52.3, 54.4, 57.9 and 67.4 were indexed to (100), (012), (104), (110), (113), (024), (114), (018), (116) and (214) respectively [19, 20].

On the surface of $\mathrm{CdO}$, the loading of $\mathrm{Al}_{2} \mathrm{O}_{3}$ NPs in NCs was supported by peaks corresponding to both $\mathrm{CdO}$ and $\mathrm{Al}_{2} \mathrm{O}_{3}$. Here, the variation in intensity of the peaks corresponding to pristine counter parts compared with pure $\mathrm{CdO}$ and $\mathrm{Al}_{2} \mathrm{O}_{3}$ signifies the formation of heteroconnected mixture of samples at varied amount of constituents [B. H. Park 2020]. The interface formed in $\mathrm{CdO} / \mathrm{Al}_{2} \mathrm{O}_{3}$ is judged to be created between random two particles due to the deposition of nano- $\mathrm{Al}_{2} \mathrm{O}_{3}$ spheres on $\mathrm{CdO}$ nano-plates. It is expected that there will not be a constant arrangements of atoms in different grains which is consistent with HRTEM and SAED analysis. Therefore this leads to the formation of oxygen defects at the $\mathrm{CdO} / \mathrm{Al}_{2} \mathrm{O}_{3}$ interface. Several literatures reported that the crystal lattice with formation of oxygen defects pose a beneficial effect on the catalyst performance as it lead to the increased adsorption sites in the material [J.A. Nasir 2018]. The narrow interface formation may help in reducing resistance in charge transfer that could be beneficial in enhancing photocatalyst performance [B. H. Park 2020]. Meanwhile, 
the $\mathrm{CdO}$ and $\mathrm{Al}_{2} \mathrm{O}_{3}$ mean crystallite size corresponding to the planes (102) and (116) was determined by applying Scherer's equation [N. Rani, 2019]. The respective sizes of the specific crystal faces were 125.1 and 14.0 for $\mathrm{CdO}$ and $\mathrm{Al}_{2} \mathrm{O}_{3}$.

\subsubsection{FTIR}

The various bonds present in the NCs were determined by FTIR analysis based on the vibrational transition of bonds (Fig. 2a). In $\mathrm{CdO} / \mathrm{Al}_{2} \mathrm{O}_{3}$, the peak denoting $\mathrm{M}-\mathrm{O}$ for $\mathrm{Al}-\mathrm{O}$ and $\mathrm{Cd}-$ $\mathrm{O}$ are noted at $421 \mathrm{~cm}^{-1}$ [21].The peak obtained at $1067 \mathrm{~cm}^{-1}$ and $1406 \mathrm{~cm}^{-1}$ denotes the non bridging M-O terminal group and O-H bending respectively [22]. In $\mathrm{CdO}$, peak at $1405 \mathrm{~cm}^{-1}$ has indicated $\mathrm{O}-\mathrm{H}$ bond [22]. Peaks at low wavenumbers were due to $\mathrm{M}-\mathrm{O}$ bond [21]. Wide peak observed at $3276 \mathrm{~cm}^{-1}$ was ascribed to stretching of $\mathrm{OH}$ [23]. In $\mathrm{Al}_{2} \mathrm{O}_{3}$, $\mathrm{Al}-\mathrm{O}-\mathrm{Al}$ bond was denoted by the bands near 650 and $967 \mathrm{~cm}^{-1}$ and the peak obtained at 500 and $1068 \mathrm{~cm}^{-1}$ were resulted from non-bridging Al-O terminal group [21, 22].

\subsubsection{UV-visible-DRS}

The optical bandgap of the NCs was determined by DRS analysis and Kubelka-Munk method by the below equation [24]:

$F(R) h v^{2}=A\left(h v-E_{g}\right)$

where planck's constant, bandgap, Kubelka-Munk function and the light frequency were denoted as $\mathrm{h}, \mathrm{E}_{\mathrm{g}}, \mathrm{F}(\mathrm{R})$ and $v$ respectively. From Kubelka-Munk plot, the calculated $E_{g}$ values of pure $\mathrm{CdO}, \mathrm{Al}_{2} \mathrm{O}_{3} \mathrm{NPs}$ and $\mathrm{CdO} / \mathrm{Al}_{2} \mathrm{O}_{3} \mathrm{NCs}$ were $2.73,3.94$ and $2.95 \mathrm{eV}$ (Fig. 2b). The synergistic effect facilitates visible-light sensitization compared to pure $\mathrm{Al}_{2} \mathrm{O}_{3}$. Hence, more amount of energy from natural sunlight will be utilized by the fabricated nanohybrid. The narrow bandgap of pristine $\mathrm{CdO}$ makes it visible light absorptive material. Nevertheless, the deposition of $\mathrm{Al}_{2} \mathrm{O}_{3}$ 
increases wide-visible range absorption from solar spectrum owing to the significance of presence of structural defects, and variation in energy band composition [M. R Islam, 2021].

\subsubsection{Photoluminescence}

The electron-hole pair migration in semiconductor nanohybrids was determined by photoluminiscence. The $\mathrm{CdO} / \mathrm{Al}_{2} \mathrm{O}_{3} \mathrm{NCs}$ PL spectrum was measured at excitation wavelength of $400 \mathrm{~nm}$ in room temperature. PL mainly exhibit two types of band: 1) shorter wavelength corresponds to near band edge emission and 2) longer wavelength, corresponds to trap-state emission. Many literatures such as Davar et al. [23] and Gadallah et al. [24] reported two types of band emmision. In beginning, excitation photon at $400 \mathrm{~nm}$ gets absorbed. Afterward, the $\mathrm{e}^{-}$ gets excited simultaneously from valence band (VB) to conduction band (CB) of CdO. A hole is left in VB of CdO. Hence an exciton was formed. The excited $\mathrm{e}^{-}$moves from $\mathrm{CB}$ of $\mathrm{CdO}$ to underlying defects level of $\mathrm{Al}_{2} \mathrm{O}_{3}$ [42]. Here, quenching occurs due to e transfer instead of $\mathrm{e}^{-} / \mathrm{h}^{+}$ recombination that give rise to a PL photon. This result implied the decrease in PL intensity of $\mathrm{NCs}$ than that of their individual precursors $\left(\mathrm{Al}_{2} \mathrm{O}_{3}\right.$ and $\left.\mathrm{CdO}\right)$ due to quenching mechanism. The $\mathrm{e}^{-} / \mathrm{h}^{+}$pair recombination of $\mathrm{CdO} / \mathrm{Al}_{2} \mathrm{O}_{3} \mathrm{NCs}$ was prevented by interface formation indicating the presence of oxygen defects. An $\mathrm{e}^{-}$transfer like this is of great interest in the application of photocatalysis. Generally, distance between interfaces governs the increase or decrease in intensity of luminescence. When there is an intimate contact, interfacial $\mathrm{e}^{-}$migration between $\mathrm{CdO}$ and $\mathrm{Al}_{2} \mathrm{O}_{3}$ results decreased $\mathrm{PL}$ intensity, known as luminescence quenching. Here the better photocatalytic efficiency corresponds to the enhanced lifetime of charge carriers.

\subsection{6 $\mathrm{N}_{2}$ adsorption/desorption studies}

The photocatalytic performance of $\mathrm{CdO} / \mathrm{Al}_{2} \mathrm{O}_{3}$ was critically influenced by the surface area and porosity. $\mathrm{N}_{2}$ sorption isotherm is depicted in Supllementary material Fig. 2a. At $P / P_{0}<0.8$ (low), 
the $\mathrm{CdO} / \mathrm{Al}_{2} \mathrm{O}_{3}$ showed type IV adsorption. The overlapping of adsorption and desorption was clearly seen with a relative flat pattern. This denotes adsorption occurring in the micropores. At $\mathrm{P} / \mathrm{P}_{0}>0.8$ (high), a small lag loop is noted that may be due to the capillary agglomeration phenomenon $[\mathrm{A}]$. BET analysis was carried out for $\mathrm{CdO} / \mathrm{Al}_{2} \mathrm{O}_{3}$ and the corresponding surface area of the particle was determined to be $27.23 \mathrm{~m}^{2} / \mathrm{g}$. The specific surface area of a nanomaterial is greatly related to its size, the smaller the material, the higher is the surface area. The CdO and $\mathrm{Al}_{2} \mathrm{O}_{3}$ NPs possess the surface area of 19.11 and $21.42 \mathrm{~m}^{2} / \mathrm{g}$ respectively. The high surface area of NCs provides more active sites. The mean pore volume and mean pore size of $\mathrm{CdO} / \mathrm{Al}_{2} \mathrm{O}_{3}$ were $0.151 \mathrm{~cm}^{3} / \mathrm{g}$ and $3.2 \mathrm{~nm}$ respectively. The pore volume and size of CdO was $0.123 \mathrm{~cm}^{3} / \mathrm{g}$ and $2.4 \mathrm{~nm}$ and for $\mathrm{Al}_{2} \mathrm{O}_{3}$ were $0.134 \mathrm{~cm}^{3} / \mathrm{g}$ and $2.7 \mathrm{~nm}$ respectively.

\subsubsection{X-ray photoelectron spectroscopy and oxygen vacancy investigation}

Chemical states in NCs were determined using XPS analysis (Fig. 3). The major components of $\mathrm{CdO} / \mathrm{Al}_{2} \mathrm{O}_{3} \mathrm{NCs}$ were observed as $\mathrm{Al}, \mathrm{O}$ and $\mathrm{Cd}$ with no unwanted elements and contaminants. Lattice oxygen vacancy in $\mathrm{CdO} / \mathrm{Al}_{2} \mathrm{O}_{3}$ : The deconvolated peaks of $\mathrm{O} 1 \mathrm{~s}$ provide two components at 529.9 and 531.1 . The band at 529.9 corresponds to $\mathrm{M}-\mathrm{O}$ oxygen that is the characteristic $\mathrm{O}^{2-}$ ions of the surface lattice oxygen in $\mathrm{CdO} / \mathrm{Al}_{2} \mathrm{O}_{3}$ matrix. The typical oxygen vacancy formed in metal oxide NCs was identified by higher energy band at $531.1 \mathrm{eV}$ attributed to the structural oxygen defects [S. Jain 2019]. The presence of the vacancy promotes the adsorption of $\mathrm{H}_{2} \mathrm{O}$ and also increases the migration of $\mathrm{e}^{-}$which facilitates charge separation [B. H. Park 2020]. A peak at $66.8 \mathrm{eV}$ was noted in $\mathrm{Al} 2 \mathrm{p}$ core level scan ascribed to $\mathrm{Al}_{2} \mathrm{O}_{3}$ presence [27]. The core level scan of $\mathrm{Cd} 3 \mathrm{~d}$ spectrum showed two components at $403.8 \mathrm{eV}\left(\mathrm{Cd} 3 \mathrm{~d}_{5 / 2}\right)$ and $410.6 \mathrm{eV}\left(\mathrm{Cd}_{3} \mathrm{~d}_{3 / 2}\right)$ [28].

\subsubsection{EIS analysis}


The charge transfer in NCs was examined by EIS analysis and Nyquist plot (Supplementary material Fig. S2). The Nyquist plot obtained fitted with Randle's equivalent circuit model to represent it in semicircle form that denotes the charge transfer resistance [P.C. Dey 2019]. The small arc radius in NCs indicates smaller the charge transfer resistance and the better migration of charges than $\mathrm{CdO}$ and $\mathrm{Al}_{2} \mathrm{O}_{3}$. The results suggest us that the $\mathrm{NCs}$ have effective e-/h+ migrations.

\subsection{Photocatalytic activity}

\subsubsection{Dye degradation}

During photocatalysis, the $\mathrm{MB}$ dye degradation in presence of $\mathrm{CdO}-\mathrm{Al}_{2} \mathrm{O}_{3}$ under visible light irradiation was recorded for $120 \mathrm{~min}$. Fig. 4a depicts the MB spectra that possess the absorption maximum at $665 \mathrm{~nm}[29,30,31]$. The chromogenic group in MB dye resulted in the absorption at $665 \mathrm{~nm}$ in the visible light spectrum. The reducing absorbance value of $\lambda_{\max }$ directly corresponds to the decolourization of cationic $\mathrm{MB}$ dye indicating the degradation of $\mathrm{MB}$ chromophore.

\subsubsection{Half-life calculation}

The intersection of graph plotted between the time and $C_{t} / C_{0}$ and $1-C_{t} / C_{0}$ was used to evaluate the half life of MB dye and it is represented in Fig. 4b. The $t_{1 / 2}$ of MB was found to be $80 \mathrm{~min}$ in the presence of NCs.

\subsubsection{Synergetic effect}

The degradation efficiency of $\mathrm{CdO} / \mathrm{Al}_{2} \mathrm{O}_{3}$ was compared with pristine $\mathrm{CdO}$ and $\mathrm{Al}_{2} \mathrm{O}_{3}$ to ensure the enhanced synergetic effect of fabricated $\mathrm{CdO} / \mathrm{Al}_{2} \mathrm{O}_{3}$. In fig. 5a, the combined effect of NCs as $\mathrm{CdO}-\mathrm{Al}_{2} \mathrm{O}_{3}$ was observed; this indicated the better efficiency of NCs than individual $\mathrm{CdO}$ and $\mathrm{Al}_{2} \mathrm{O}_{3}$ in dye degradation. The kinetic rate constant of $\mathrm{CdO} / \mathrm{Al}_{2} \mathrm{O}_{3}$ was observed to be $14 \times$ 
$10^{-3}$ which was 3.5 times higher than $\mathrm{CdO}\left(4 \times 10^{-3}\right)$ and 14 times higher than the pristine $\mathrm{Al}_{2} \mathrm{O}_{3}$ $\left(1 \times 10^{-3}\right)$ (Fig 5b). The degradation percentage of $\mathrm{CdO}-\mathrm{Al}_{2} \mathrm{O}_{3}, \mathrm{CdO}$ and $\mathrm{Al}_{2} \mathrm{O}_{3}$ are represented in Fig. 5c, obtained after $220 \mathrm{~min}$ of visible light irradiation. The degradation percentage of CdO$\mathrm{Al}_{2} \mathrm{O}_{3}$ was $97.3 \%$, and it was higher compared to $\mathrm{CdO}(64 \%)$ and $\mathrm{Al}_{2} \mathrm{O}_{3}(27 \%)$ which might be the result of increased photocatalytic activity of NCs by enhanced light absorption. The heterojunction formation results in reduced recombination of photogenerated $\mathrm{e}^{-} / \mathrm{h}^{+}$pair [33]. Further, total organic carbon (TOC) analyzer was used to measure TOC of the treated solution to provide some mineralization results as indicated in following equation:

$$
\text { TOC removal }(\%)=100 \times\left(1-\frac{[\mathrm{TOC}]_{t}}{[\mathrm{TOC}]_{0}}\right)
$$

where $[\mathrm{TOC}]_{0}$ and $[\mathrm{TOC}]_{\mathrm{t}}$ are the TOC values of the solution in $\mathrm{mg} \mathrm{L}^{-1}$ at time 0 and time $t$, respectively. Similar to decolourization (97.3\%) in $160 \mathrm{~min}$, high TOC removal (87\%) was attained for $\mathrm{CdO} / \mathrm{ZnFe}_{2} \mathrm{O}_{4} \mathrm{NCs}$. $\mathrm{MB}$ molecules come in contact with $\cdot \mathrm{OH}$ and oxidize incompletely that may lead to the production of several intermediates. The high TOC removal indicates the high level of mineralization of $\mathrm{MB}$ under visible light irradiation.

\subsubsection{Influence of NCs dosage}

The effect of NCs in dye degradation was evaluated by using varying amount of photocatalyst from 5 to $20 \mathrm{mg}$. It has been observed that the increase in NCs amount enhanced the degradation efficiency which is represented in the supplementary material in fig.S3a. The increasing concentrations of the NCs quantity correspond to the better degradation of the MB dye. The active sites in the NCs played a vital role in degradation of MB dye. More active sites were observed when the concentration of $\mathrm{MB}(25 \mathrm{mg} / \mathrm{L})$ was kept constant with an increasing NCs quantity. Here, the path length remained constant whereas the number of photons reaching to the 
NCs surface increased as the colour intensity of the MB is same. This paved the way for more generation of free radicals.

\subsubsection{Kinetics study}

Several degradation processes are understood based on the degradation kinetics using Langmuir and Freundlich isotherm. Langmuir isotherm is the best method to understand active sites with same energy whereas the available sites with unequal energies and heterogeneity are indicated by Freundlich isotherm [34]. At weak absorbance and lower concentration of MB, Langmuir Hinshelwood equation (L-H) is exploited for evaluating the reaction kinetic [35]. The simplified L-H given as follows:

$R=\frac{d C}{d t}=-k C$

The above equation is integrated to:

$\operatorname{Ln}(C)=-k t+\operatorname{Ln}\left(C_{0}\right)$

where $\mathrm{k}$ and $\mathrm{C}_{0}$ denotes the first order kinetics reaction constant and the initial concentration of MB respectively. The graph plotted between $\ln \mathrm{C}_{\mathrm{t}} / \mathrm{C}_{0}$ and time ( 0 to $220 \mathrm{~min}$ ) was used to evaluate first order kinetics constant for varied NCs quantity [36]. As per the literatures, experimental data with high regression coefficients $\left(\mathrm{R}^{2}=0.923\right.$ to 0.962$)$ for varied NCs concentration best suits for Langmuir isotherm model $[37,38]$. MB molecules have an equal affinity on the active sites of NCs, hence at the time of absorption, MB could provide a monolayer coverage on surface of NCs. The k value was found to be $18 \times 10^{-3}, 17 \times 10^{-3}, 14 \times$ $10^{-3}$ and $9 \times 10^{-3}$ for varying quantity of NCs as $20,15,10$ and $5 \mathrm{mg}$ respectively (Supplementary material Fig. S3b). The rate constant of $\mathrm{MB}$ in the absence of $\mathrm{CdO} / \mathrm{Al}_{2} \mathrm{O}_{3}$ has been obtained as $0.9 \times 10^{-3}$ under irradiation of visible light, which proves that the dye degradation was carried by the action of NCs indeed. 


\subsubsection{Stability and reusability}

In dye degradation, the particle stability is a critical factor as the photocatalytic activity. The similar protocol is followed on subsequent repeated cycles for degradation. The degradation percentage of MB was calculated on each cycle (fig 6a).The degradation percentage of $\mathrm{MB}$ for the $1^{\text {st }}$ run was observed to be $97.3 \%$, which was sustained with a negligible difference even after the $6^{\text {th }}$ run $(96.6 \%)$, indicating the high stability and reusing capacity of $\mathrm{CdO}-\mathrm{Al}_{2} \mathrm{O}_{3}$. In addition, the structural stability of the photocatalyst was monitored by performing XRD, TEM and XPS analysis of recovered NCs. The XPS showed negligible change in the pattern and intensity that ensured that the particles were free from photo-corrosion. Stability was further confirmed by XRD analysis of the recycled NCs irradiated under light after photocatalysis. The negligible changes in peak indicate the photostability and non-corrosive nature of particles (Supplementary figure S4a). Further the TEM analysis (Supplementary figure S4b) verified that there was no change in morphology of NCs.

\subsection{Possible mechanism}

\subsubsection{Scavengers study}

The reaction mechanism of the dye degradation was evaluated by scrutinizing the role of each reactive species. The available free electrons were quenched by the scavengers and thus declining the photocatalytic activity. Higher reduction in the degradation activity corresponded to the vital role of a particular radical. In this report, EDTA, $\mathrm{AgNO}_{3}$, isopropyl alcohol, and pbenzoquinone were exploited to quench the $\mathrm{h}^{+}, \mathrm{e}^{-}, \mathrm{OH}^{-}$and $\mathrm{O}_{2}^{-}$respectively. In fig. $6 \mathrm{~b}$ reduction in degradation has been observed in the order of isopropyl alcohol $>$ EDTA $>\mathrm{AgNO}_{3}>$ pbenqoquinone. It indicates the $\cdot \mathrm{OH}$ as a major contributor followed by $\mathrm{h}^{+}$and $\mathrm{e}^{-}$.

\subsubsection{CdO catalyst performance}


Due to the narrow bandgap of $\mathrm{CdO}(2.73 \mathrm{eV})$, it is active in visible region (Fig. 7 Scheme 1) [39]. The photoinduced $\mathrm{e}^{-}$excited from the Valence band (VB) of CdO to the conduction band (CB) under visible light irradiation. Nevertheless, as a single system photocatalyst, the photoinduced $\mathrm{e}^{-} / \mathrm{h}^{+}$pair recombines faster. This results in decreased lifetime of charge carriers. This makes fewer $\mathrm{e}^{-} / \mathrm{h}^{+}$pairs available for the photo-degradation of dye. The $\mathrm{h}^{+}$react with water to generate free radical $\left(\mathrm{OH}^{\circ}\right)$. The $\mathrm{MB}$ dye is attacked and oxidized by generated radicals with the release of $\mathrm{H}_{2} \mathrm{O}$ and $\mathrm{CO}_{2}$.

\subsection{3 $\mathrm{Al}_{2} \mathrm{O}_{3}$ catalyst performance}

$\mathrm{Al}_{2} \mathrm{O}_{3}$ possess relatively large bandgap $(3.94 \mathrm{eV})$ that makes it active in $\mathrm{UV}$ region [40]. The Under visible-light irradiation, there is no photo-excitation of $\mathrm{e}^{-}$in $\mathrm{Al}_{2} \mathrm{O}_{3}$. It resulted in reduced photocatalytic performance compared to $\mathrm{CdO}$ under visible light (Fig. 7 Scheme 2).

\subsubsection{Photocatalytic activity of $\mathrm{CdO} / \mathrm{Al}_{2} \mathrm{O}_{3} \mathrm{NCs}$}

The schematic representation was photocatalysis mechanism is represented in (Fig. 7 Scheme 3). The bandgap of $2.95 \mathrm{eV}$ facilitates visible light photocatalysis with enhanced utilization of energy [41]. The $\mathrm{e}^{-}$jumps from (VB) valance band to the (CB) conduction band of $\mathrm{CdO}$ under visible light irradiation, which leaves behind an $\mathrm{h}^{+}$in $\mathrm{VB}$ of $\mathrm{CdO}$. Although $\mathrm{Al}_{2} \mathrm{O}_{3} \mathrm{CB}$ potential is higher, the photo-excited e-from $\mathrm{CdO}$ tends to migrate to low lying $\mathrm{Al}_{2} \mathrm{O}_{3}$ defect levels. Owing to its porous nature, the $\mathrm{Al}_{2} \mathrm{O}_{3}$ act as electron sink as it contains more number of defect sites [42]. This aids $\mathrm{e}^{-} / \mathrm{h}^{+}$pair separation [8]. The role of $\mathrm{Al}_{2} \mathrm{O}_{3}$ is to provide support and not used to facilitate activity in visible region. The position of $\mathrm{CB}$ in $\mathrm{Al}_{2} \mathrm{O}_{3}$ does not be able to participate in charge transfer. Therefore, $\mathrm{Al}_{2} \mathrm{O}_{3}$ alone does not give any activity. On contrary, $\mathrm{CdO}$ with a small bandgap is sensitive in the visible region. $\mathrm{Al}_{2} \mathrm{O}_{3}$ was selected as support due to its low cost, non-toxic and stable nature [43]. Further, electric field induced between n-type $\mathrm{CdO}$ and p-type 
$\mathrm{Al}_{2} \mathrm{O}_{3}$ heterojunction, the photo-generated $\mathrm{e}^{-/ \mathrm{h}^{+}}$separations are made quite comfortable. This interfacial charge transfer increases the life time of $\mathrm{e}^{-} / \mathrm{h}^{+}$. Hence, photocatalytic activity is enhanced for NCs. The enriched $\mathrm{h}^{+}$accumulation on VB of CdO reacts with available water to form radicals. The formed $\mathrm{OH} \cdot$ radicals subsequently degrade the dye molecules by releasing $\mathrm{CO}_{2}$ and $\mathrm{H}_{2} \mathrm{O}[44]$.

\subsection{Anti-bacterial activity}

In Fig. 8a, the role of NCs against S. aureus, B, subtilis, P. aeruginosa and E. coli as an antibacterial agent has been shown. Varying NPs concentration $(0.1$ to $100 \mathrm{mg} / \mathrm{L})$ has been studied for toxicity. It has been observed that the toxicity increased in accordance with the NPs concentration. As compared to S. aureus, P. aeruginosa and B. subtilis, the E. coli has been observed to be more sensitive. After NCs interaction, P. aeruginosa, S. aureus, B. subtilis and E. coli growth was inhibited to $71,55,46$ and $87 \%$ for $10 \mathrm{mg} / \mathrm{L}$ and all species showed $100 \%$ growth inhibition for $100 \mathrm{mg} / \mathrm{L}$ NCs concentration. The toxicity of individual particle (CdO and $\mathrm{Al}_{2} \mathrm{O}_{3}$ ) exhibited the same tendency but with lower toxicity in comparison with NCs. (Fig 8b and

c) This in turn indicated the higher ROS generation in NCs. When subjected to $100 \mathrm{mg} / \mathrm{L}$ of nanoparticle, $\mathrm{CdO}$ toxicity upon $P$. aerunginosa, S. aureus, B. subtilis and E. coli were observed as $73,46,35$ and $84 \%$ respectively and for $\mathrm{Al}_{2} \mathrm{O}_{3}$ it was $49,28,23$ and $67 \%$ respectively. As gram negative bacteria with a thin peptidoglycan wall, E. coli showed enhanced penetration of NCs leading to its increased toxicity [46].The nano-sized particles led to generation of more amounts of ROS species. ROS interaction leads to damage in cellular proteins that induce apoptosis. When NPs incorporate cytoplasm, they can induce plasma membrane damage alters cell permeability. Further the NPs penetrate inside the nucleus which may lead to DNA damages via point mutations. This results in arrested cell division. Therefore the growth is inhibited. Also, 
positive ions release form NPs, if any will interact with the negatively charged bacterial cell membrane. This action prohibits the permeability of the proteins by entering into the cell membrane ultimately lead to bacterial death [47].

\section{Conclusion}

The photocatalytic activity of $\mathrm{CdO} \mathrm{NCs}$ was enhanced after fabrication of $\mathrm{Al}_{2} \mathrm{O}_{3}$. The $\mathrm{NCs}$ was prepared by chemical co-precipitation method. XRD, TEM, FTIR, XPS and BET analysis were used for the characterization of NCs. The kinetic rate constant was $14 \times 10^{-3}$ for NCs which was 14 times higher than $\mathrm{Al}_{2} \mathrm{O}_{3}\left(1 \times 10^{-3}\right)$ and 3.5 times higher than $\mathrm{CdO}\left(4 \times 10^{-3}\right)$, respectively. The NCs also exhibited excellent antimicrobial activity against all the mentioned bacteria. The degradation exhibited first order kinetic trend. The hydroxyl radical served a vital role in the mechanism of dye degradation. Even after six cycles, the NC expressed good stability and reusability.

\section{Acknowledgement}

Authors sincerely thank the management of Bannari Amman Institute of Technology, Tamil Nadu for providing the necessary facilities for carrying out this work.

\section{References}

[1] S. B. Khan, F. Ali, T. Kamal, Y. Anwar, A. M. Asiri, J. Seo, CuO embedded chitosan spheres as antibacterial adsorbent for dyes, International Journal of Biological Macromolecules, 88 (2016) 113-119.

[2] A. K. Dutta, U. K. Ghorai, K. K. Chattopadhyay, D. Banerjee, Removal of textile dyes by carbon nanotubes: A comparison between adsorption and UV assisted photocatalysis, Physica E: Low-dimensional Systems and Nanostructures, 99 (2018) 6-15.

[3] P. Dash, A. Manna, N. C. Mishra, S. Varma, Synthesis and characterization of aligned ZnO nanorods for visible light photocatalysis, Physica E: Low-dimensional Systems and Nanostructures, 107 (2019) 38-46.

[4] I. Ahmad, S. B. Khan, T. Kamal, A. M. Asiri, Visible light activated degradation of organic pollutants using zinc-iron selenide, Journal of Molecular Liquids, 229 (2017) 429-435 
[5]N. Ali, A. khan, A. Riaz, A. M. Asiri, T. Kamal, Photocatalytic performance evaluation of bismuth doped tin-dioxide under UV and direct sunlight irradiation for congo red dye degradation, Journal of the Chemical Society of Pakistan, 42 (2020) 687-695.

[6] S. Balamurugan, A. R. Balu, V. Narasimman, G. Selvan, K. Usharani, J. Srivind, M. Suganya, N. Manjula, C. Rajashree, V. S. Nagarethinam, Multi metal oxide $\mathrm{CdO}-\mathrm{Al}_{2} \mathrm{O}_{3}-\mathrm{NiO}$ nanocomposite - synthesis, photocatalytic and magnetic properties, Materials research express, 6 (2019) 015022.

[7] W. N. Zhang, J. L. Tu, A. Aierken, G. Y. Song, X. Z. Xu, P. Y. Yan, X. Y. Sun, K. Hu, L. Li, P. Q. Xu, Effect of $1 \mathrm{MeV}$ electron irradiation on $\mathrm{TiO}_{2} / \mathrm{Al}_{2} \mathrm{O}_{3} / \mathrm{MgF}_{2}$ anti-reflective coating for GaInP/InGaAs/Ge triple junction solar cells, Optical Materials, 109 (2020) 110278.

[8] A. Kanwal, S. Sajjad, S. A. K. Leghari, Z. Yousaf, Cascade electron transfer in ternary $\mathrm{CuO} / \alpha-\mathrm{Fe}_{2} \mathrm{O}_{3} / \gamma-\mathrm{Al}_{2} \mathrm{O}_{3}$ nanocomposite as an effective visible photocatalyst, Journal of Physics and Chemistry of Solids, 151 (2021) 109899.

[9] D. Liu, J. Robertson, Oxygen vacancy levels and interfaces of $\mathrm{Al}_{2} \mathrm{O}_{3}$, Microelectronic Engineering, 86 (2009) 1668-1671.

[10] S. Ateş, E. Baranb, B. Yazıcı, The nanoporous anodic alumina oxide formed by two-step anodization, Thin Solid Films, 648 (2018) 94-102.

[11] S.Z. Chu, K. Wada, S. Inoue, M. Isogai, Y. Katsuta, A. Yasumori, Large-Scale fabrication of ordered nanoporous alumina films with arbitrary pore intervals by critical-potential anodization, Journal of the Electrochemical Society, 153 (2006) 384-391.

[12] T.S. Shih, P.S. Wei, Y.S. Huang, Optical properties of anodic aluminum oxide films on Al1050 alloys, Surface and Coatings Technology, 202 (2008) 3298-3305.

[13] W.M. de Azevedoa, D.D. de Carvalho, H.J. Khoury, E.A. de Vasconcelos, E.F. da Silva, Spectroscopic characteristics of doped nanoporous aluminum oxide, Materials Science and Engineering, 112 (2004) 171-174.

[14] S. Kumar, A.K. Ojha, B. Walkenfort, Cadmium oxide nanoparticles grown in situ on reduced graphene oxide for enhanced photocatalytic degradation of methylene blue dye under ultraviolet irradiation, Journal of Photochemistry and Photobiology B: Biology, 159 (2016) 111 119.

[15] R. Henríquez, P. Grez, E. Muñoz, E.A. Dalchiele, R.E. Marotti, H. Gómez, Template-free non-aqueous electrochemical growth of CdO nanorods, Thin Solid Films, 520 (2011) 41-46.

[16] J. Chang, R.S. Mane, D. Ham, W. Lee, B.W. Cho, J.K. Lee, S.-H. Han, Electrochemical capacitive properties of cadmium oxide films, Electrochimica Acta, 53 (2007) 695-699.

[17] S. Jia, Y. Feng, H. Zhang, D. Jiang, Q. Zhan, Interface engineered fabrication of $\mathrm{Bi}_{4} \mathrm{O}_{7} / \mathrm{BiOCl} 1 \mathrm{D} / 2 \mathrm{D}$ p-n heterojunction for enhanced visible light driven photocatalysis, Optical Materials, 109 (2020) 110174. 
[18] J. Zhang, B. Qiao, Z. Liang, P. Zuo, Q. Wu, Z. Xu, L. Piao, S. Zhao, Near-infrared lightinduced photocatalysis of $\mathrm{NaYF}_{4}: \mathrm{Yb}, \mathrm{Tm} @ \mathrm{Cu}_{2} \mathrm{O}$ core-shell nanocomposites, Optical Materials, 84 (2018) 89-93.

[19] M. T. S. Chani, S. B. Khan, A. M. Asiri, K. S. Karimov, M. A. Rub, Photo-thermoelectric cells based on pristine $\alpha-\mathrm{Al}_{2} \mathrm{O}_{3}$ co-doped CdO, CNTs and their single and bi-layer composites with silicone adhesive, Journal of the Taiwan Institute of Chemical Engineers, 52 (2015) 93-99.

[20] M. M. Alam, M. M. Rahman, M. T. Uddin, A. M. Asiri, Inamuddin, M. T. S. Chani, M. A. Islam, Development of l-glutamic acid biosensor with ternary $\mathrm{ZnO} / \mathrm{NiO} / \mathrm{Al}_{2} \mathrm{O}_{3}$ nanoparticles, Journal of Luminescence, 227 (2020) 117528

[21] R. Romero, V. R. Santoyo, C. D. M. Sánchez, M. M. Rosales, Effect of aluminum precursor on physicochemical properties of $\mathrm{Al}_{2} \mathrm{O}_{3}$ by hydrolysis/precipitation method, Nova Scientia, 10 (2018) 83

[22] T. M. S. Dawoud, V. Pavitra, P. Ahmad, A. Syed, G. Nagaraju, Photocatalytic degradation of an organic dye using $\mathrm{Ag}$ doped $\mathrm{ZrO}_{2}$ nanoparticles: Milk powder facilitated eco-friendly synthesis, Journal of King Saud University - Science, 32 (2020) 1872-1878.

[23] V. Seshan, M. Sundar, Prema, On the preparation, structural and magnetic properties of ZnO:Co nanoparticles, The European Physical Journal Applied Physics, 66 (2014) 10602

[24] Y. A. Alibwaini, O. M. Hemeda, R. El-Shater, T. Sharshar, A. H. Ashour, A. Ajlouni, E. A. Arrasheed, A. M. A. Henaish, Synthesis, characterizations, optical and photoluminescence properties of polymer blend PVA/PEG films doped eosin Y (EY) dye, Optical Materials, (2020) 110600.

[25] B. Janani, A. Syed, A. M. Thomas, S. Al-Rashed, L. L. Raju, S. S. Khan,Designing spinel $\mathrm{NiCr}_{2} \mathrm{O}_{4}$ loaded $\mathrm{Bi}_{2} \mathrm{O}_{3}$ semiconductor hybrid for mitigating the charge recombination and tuned band gap for enhanced white light photocatalysis and antibacterial applications,Journal of Alloys and Compounds, (2021) 158735.

[26] A. Kumar, L. Rout, L. S. K. Achary, S. Mohanty, P. Dash, A combustion synthesis route for magnetically separable graphene oxide- $\mathrm{CuFe}_{2} \mathrm{O}_{4}-\mathrm{ZnO}$ nanocomposite with enhanced solar lightmediated photocatalytic activity, New journal of chemistry, 41 (2017) 10568-10583.

[27] G. Nie, Y. Li, P. Sheng, Z. Tian, W. Liu, H. Wu, Y. Bao, S. Wu, Fabrication of $\mathrm{Al}_{2} \mathrm{O}_{3} / \mathrm{AlN}$ composite ceramics with enhanced performance via a heterogeneous precipitation coating process, Ceramics International, 46 (2020) 21156-21 165

[28] F. Wang, B. Liu, Z. Zhang, S. Yuan, Synthesis and properties of Cd-doped ZnO nanotubes, Physica E: Low-dimensional Systems and Nanostructures, 41 (2009) 879-882.

[29]M. Goswami, Enhancement of photocatalytic activity of synthesized Cobalt doped Zinc Oxide nanoparticles under visible light irradiation, Optical Materials, 109 (2020) 110400. 
[30]A. Khalil, N. Ali, A. Khan, A. M. Asiri, T. Kamal, Catalytic potential of cobalt oxide and agar nanocomposite hydrogel for the chemical reduction of organic pollutants, International Journal of Biological Macromolecules, 164 (2020) 2922-2930.

[31]F. Ali, S. B. Khan, T. Kamal, K. A. Alamry, E. M. Bakhsh, A. M. Asiri, T. R. A. Sobahi, Synthesis and characterization of metal nanoparticles templated chitosan- $\mathrm{SiO}_{2}$ catalyst for the reduction of nitrophenols and dyes, Carbohydrate Polymers, 192 (2018) 217-230.

[32] Y.B. Kim, D. Cho, W.H. Park, Fabrication and characterization of $\mathrm{TiO}_{2} /$ poly(dimethyl siloxane) composite fibers with thermal and mechanical stability, Journal of Applied Polymer Science, 116 (2010) 449-454.

[33] J. Ma, C. Lu, C. Liu, M. Qi, X. Xu, D. Yang, X. Xu, Electrophoretic deposition of $\mathrm{ZnSnO}_{3} / \mathrm{MoS}_{2}$ heterojunction photoanode with improved photoelectric response by low recombination rate, Journal of Alloys and Compounds, 810 (2019) 151845

[34] N. Hegyesi, R.T. Vad, B. Pukánszky, Determination of the specific surface area of layered silicates by methylene blue adsorption: the role of structure, $\mathrm{pH}$ and layer charge, Applied Clay Science, 146 (2017) 50-55.

[35] I.K. Konstantinou, T.A. Albanis, $\mathrm{TiO}_{2}$-assisted photocatalytic degradation of azo dyes in aqueous solution: kinetic, mechanistic investigations: a review, Applied Catalysis B: Environmental, 49 (2004) 1-14.

[36] S.K. Mohapatra, N. Kondamudi, S. Banerjee, M. Misra, Functionalization of self- organized $\mathrm{TiO}_{2}$ nanotubes with $\mathrm{Pd}$ nanoparticles for photocatalytic decomposition of dyes under solar light illumination, Langmuir, 24 (2008) 11276-11281.

[37] A.N. Kadam, R.S. Dhabbe, M.R. Kokate, K.M. Garadkar, Room temperature synthesis of CdS nanoflakes for photocatalytic properties, Journal of Materials Science: Materials in Electronics, 25 (2014) 1887-1892.

[38] H. Li, G. Wang, F. Zhang, Y. Cai, Y. Wang, I. Deerdj, Surfactant-assisted synthesis of $\mathrm{CeO}_{2}$ nanoparticles, their application in wastewater treatment, RSC Advances, 2 (2012) 12413-12423.

[39] Ian M. Bake, II-VI Narrow Bandgap Semiconductors: Optoelectronics, Springer Handbook of Electronic and Photonic Materials, (2017) 1.

[40] A. Zarubica, R. Ljupković, J. Papan, I. Vukoje, S. Porobić, S. P. Ahrenkiel, J. M. Nedeljković, Visible-light-responsive $\mathrm{Al}_{2} \mathrm{O}_{3}$ powder: Photocatalytic study, Optical Materials, $106(2020) 110013$

[41] N. Serpone, P. Maruthamuthu, P. Pichat, E. Pelizzetti, H. Hidaka, Exploiting the interparticle electron transfer process in the photocatalysed oxidation of phenol, 2-chlorophenol and pentachlorophenol: chemical evidence for electron and hole transfer between coupled semiconductors, Journal of Photochemistry and Photobiology, 85 (1995), pp. 247-255 
[42] F. Li, Y. Zhao, Q. Wang, X. Wang, Y. Hao, R. Liu, D. Zhao, Enhanced visible-light photocatalytic activity of active $\mathrm{Al}_{2} \mathrm{O}_{3} / \mathrm{g}-\mathrm{C}_{3} \mathrm{~N}_{4}$ heterojunctions synthesized via surface hydroxyl modification, Journal of Hazardous Materials, 283 (2015) 371-381.

[43] R. Bagtache, F. Saib, K. Abdmeziem, M. Trari, A new hetero-junction p-CuO/ $/ \mathrm{Al}_{2} \mathrm{O}_{3}$ for the $\mathrm{H}_{2}$ evolution under visible light, International Journal of Hydrogen Energy, 44 (2019) 2241922424.

[44] N. T. D. Cam, H. Pham, T. Pham, T. T. T. Phuong, C. V. Hoang, M. H. T. Tung, N. T. Trung, N. T. Huong, T. T. T. Hien, Novel photocatalytic performance of magnetically recoverable $\mathrm{MnFe}_{2} \mathrm{O}_{4} / \mathrm{BiVO}_{4}$ for polluted antibiotics degradation, Ceramics International, (2020) In press

[45] I.Talat, A. Arshad, Q. Mansoor, Graphene nanoplatelets $/ \mathrm{Cr}_{2} \mathrm{O}_{3}$ nanocomposites as novel nanoantibiotics: Towards control of multiple drug resistant bacteria, Ceramics International, (2020) In press

[46] S. Zada, A. Ahmad, S. Khan, X. Yu, K. Chang, A. Iqbal, A. Ahmad, S. Ullah, M. Raza, A. Khan, S. Ahmad, P. Fu, Biogenic synthesis of silver nanoparticles using extracts of Leptolyngbya JSC-1 that induce apoptosis in HeLa cell line and exterminate pathogenic bacteria, Artificial Cells, Nanomedicine, and Biotechnology, 46 (2018) S471-S480.

[47] T. Munawar, F. Mukhtar, M. S. Nadeem, M. Riaz, M. N. ur Rahman, K. Mahmood, M. Hasan, M. I. Arshad, F. Hussain, A. Hussain, F. Iqbal, Novel photocatalyst and antibacterial agent; direct dual $\mathrm{Z}$-scheme $\mathrm{ZnO}-\mathrm{CeO}_{2}-\mathrm{Yb}_{2} \mathrm{O}_{3}$ heterostructured nanocomposite, Solid State Sciences, 109 (2020) 106446.

Figure captions 
Figure 1. Characterization of $\mathrm{CdO} / \mathrm{Al}_{2} \mathrm{O}_{3}$ NCs: (a) TEM (inset - SAED), (b) HRTEM, (c) EDAX and (d) XRD pattern of $\mathrm{CdO} / \mathrm{Al}_{2} \mathrm{O}_{3}$

Figure 2. (a) FT-IR spectrum, (b) Kubelka Munk function vs energy plot and (c) $\mathrm{CdO} / \mathrm{Al}_{2} \mathrm{O}_{3}$ photoluminescence emission

Figure 3. Full-scan XPS spectrum and corresponding deconvoluted peaks in the high resolution for $\mathrm{O} 1 \mathrm{~s}, \mathrm{Al} 2 \mathrm{p}$ and $\mathrm{Cd} 3 \mathrm{~d}$ elements of NCs.

Figure 4. (a) UV-vis spectral change of $\mathrm{MB}$ dye after addition of $\mathrm{CdO} / \mathrm{Al}_{2} \mathrm{O}_{3}$. (b) The plot of $\mathrm{C} / \mathrm{C}_{0}$ and $1-\left(\mathrm{C} / \mathrm{C}_{0}\right)$ versus time.

Figure 5. (a) The plot of $\mathrm{C} / \mathrm{C}_{0}$ versus time, (b) the plot of $\ln _{0} / \mathrm{C}$ versus time and (c) degradation (\%) for $\mathrm{CdO} / \mathrm{Al}_{2} \mathrm{O}_{3}, \mathrm{CdO}$ and $\mathrm{Al}_{2} \mathrm{O}_{3}$.

Figure 6. (a) Photocatalytic performance of $\mathrm{CdO} / \mathrm{Al}_{2} \mathrm{O}_{3}$ during six successive cycles and (b) Effect of different scavengers on photocatalytic performance.

Figure 7. Schematic representation of photocatalytic mechanism of $\mathrm{CdO} / \mathrm{Al}_{2} \mathrm{O}_{3}, \mathrm{CdO}$ and $\mathrm{Al}_{2} \mathrm{O}_{3}$.

Figure 8. The antimicrobial influence of (a) $\mathrm{CdO} / \mathrm{Al}_{2} \mathrm{O}_{3}$, (b) $\mathrm{CdO}$ and $\mathrm{Al}_{2} \mathrm{O}_{3}$ on Staphylococcus aureus, Pseudomonas aeruginosa, Escherichia coli and Bacillus subtilis 
Figures
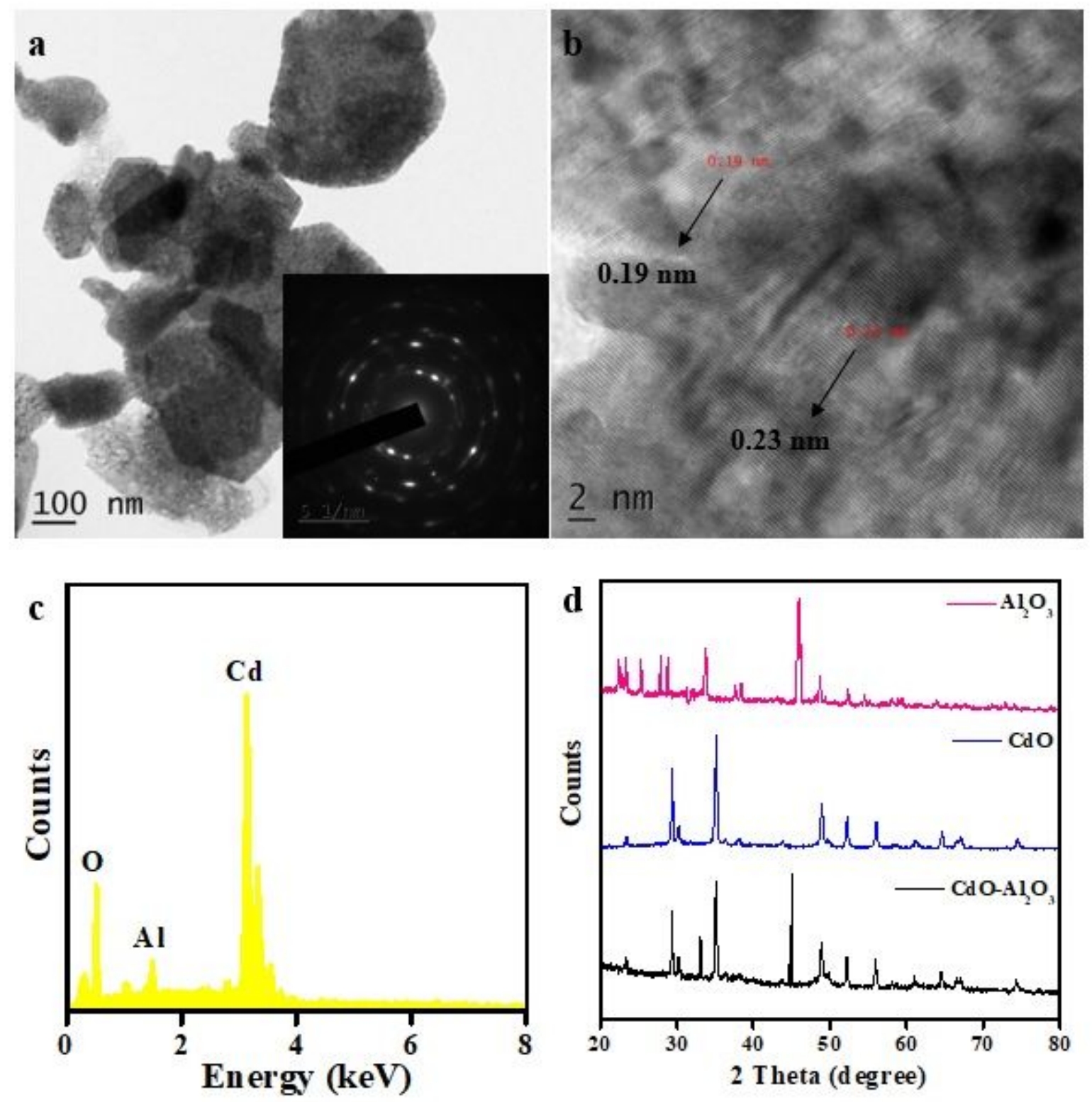

Figure 1

Characterization of CdO/Al2O3 NCs: (a) TEM (inset - SAED), (b) HRTEM, (c) EDAX and (d) XRD pattern of $\mathrm{CdO} / \mathrm{Al} 2 \mathrm{O3}$. 

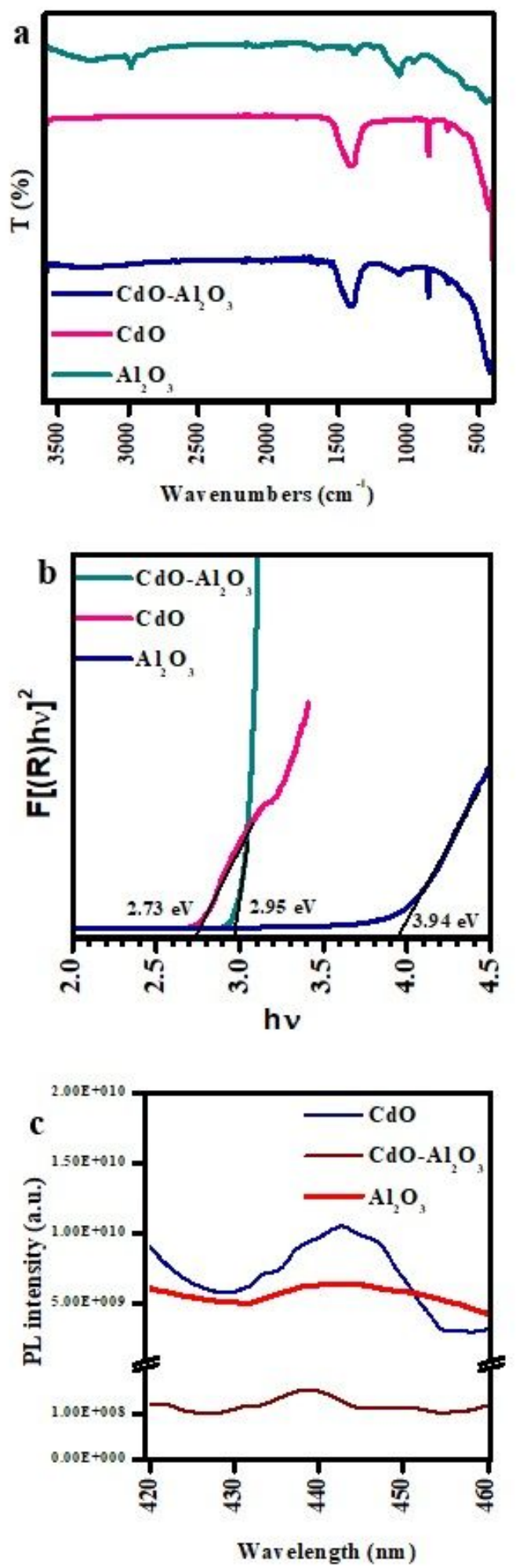

Figure 2

(a) FT-IR spectrum, (b) Kubelka Munk function vs energy plot and (c) CdO/Al2O3 photoluminescence emission 

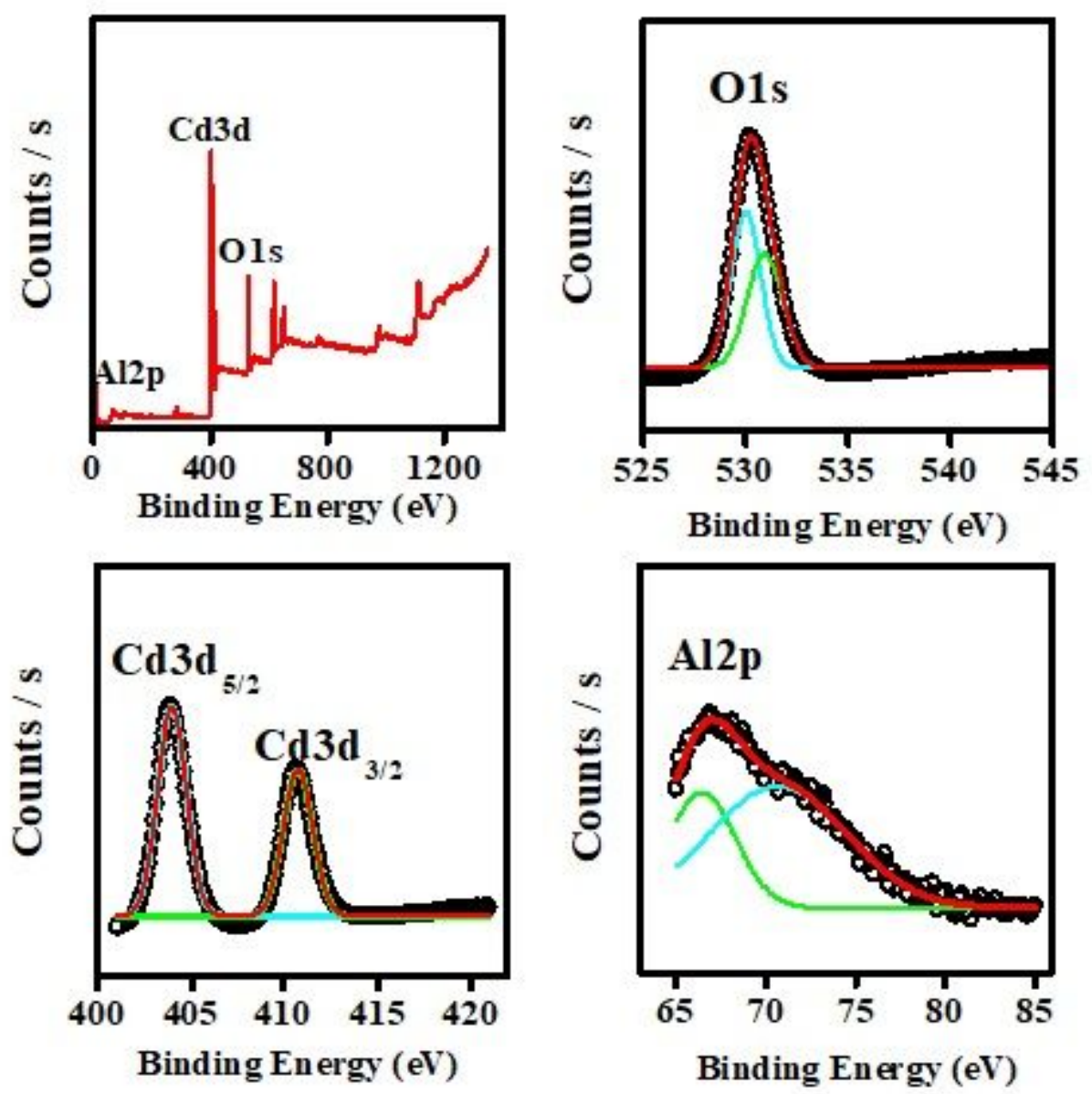

Figure 3

Full-scan XPS spectrum and corresponding deconvoluted peaks in the high resolution for 01s, Al2p and Cd3d elements of NCs.
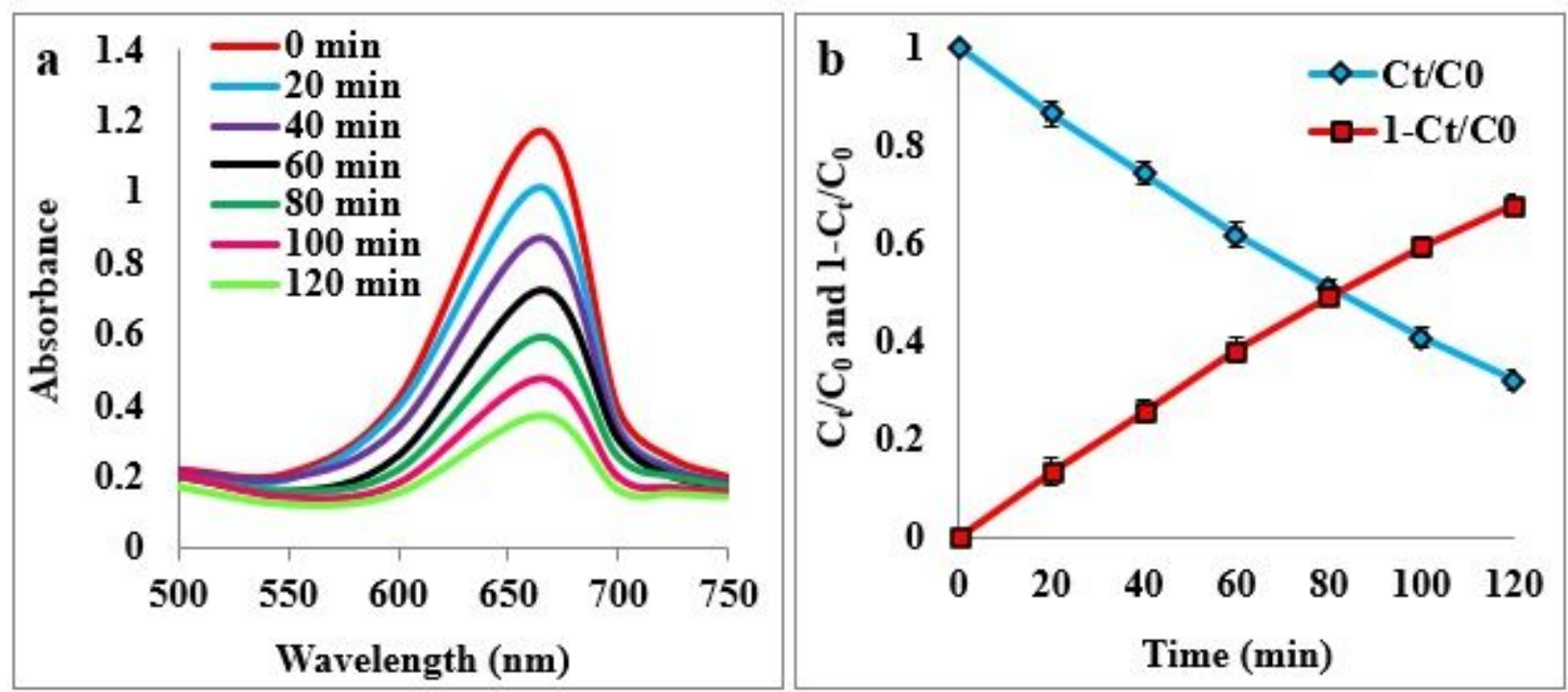

Figure 4 
(a) UV-vis spectral change of MB dye after addition of CdO/Al2O3. (b) The plot of $\mathrm{C} / \mathrm{CO}$ and 1-(C/CO) versus time.
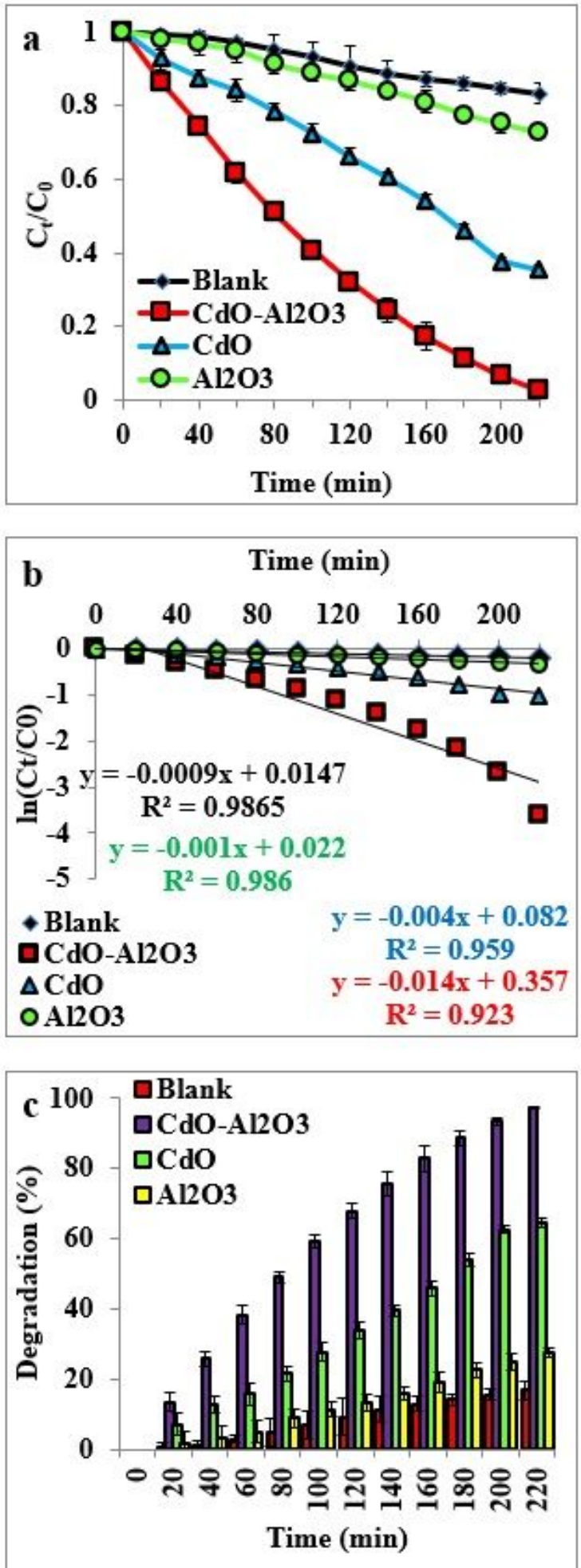

Figure 5

(a) The plot of $\mathrm{C} / \mathrm{C} 0$ versus time, (b) the plot of InC0/C versus time and (c) degradation (\%) for $\mathrm{CdO} / \mathrm{Al} 2 \mathrm{O} 3, \mathrm{CdO}$ and $\mathrm{Al} 2 \mathrm{O} 3$. 

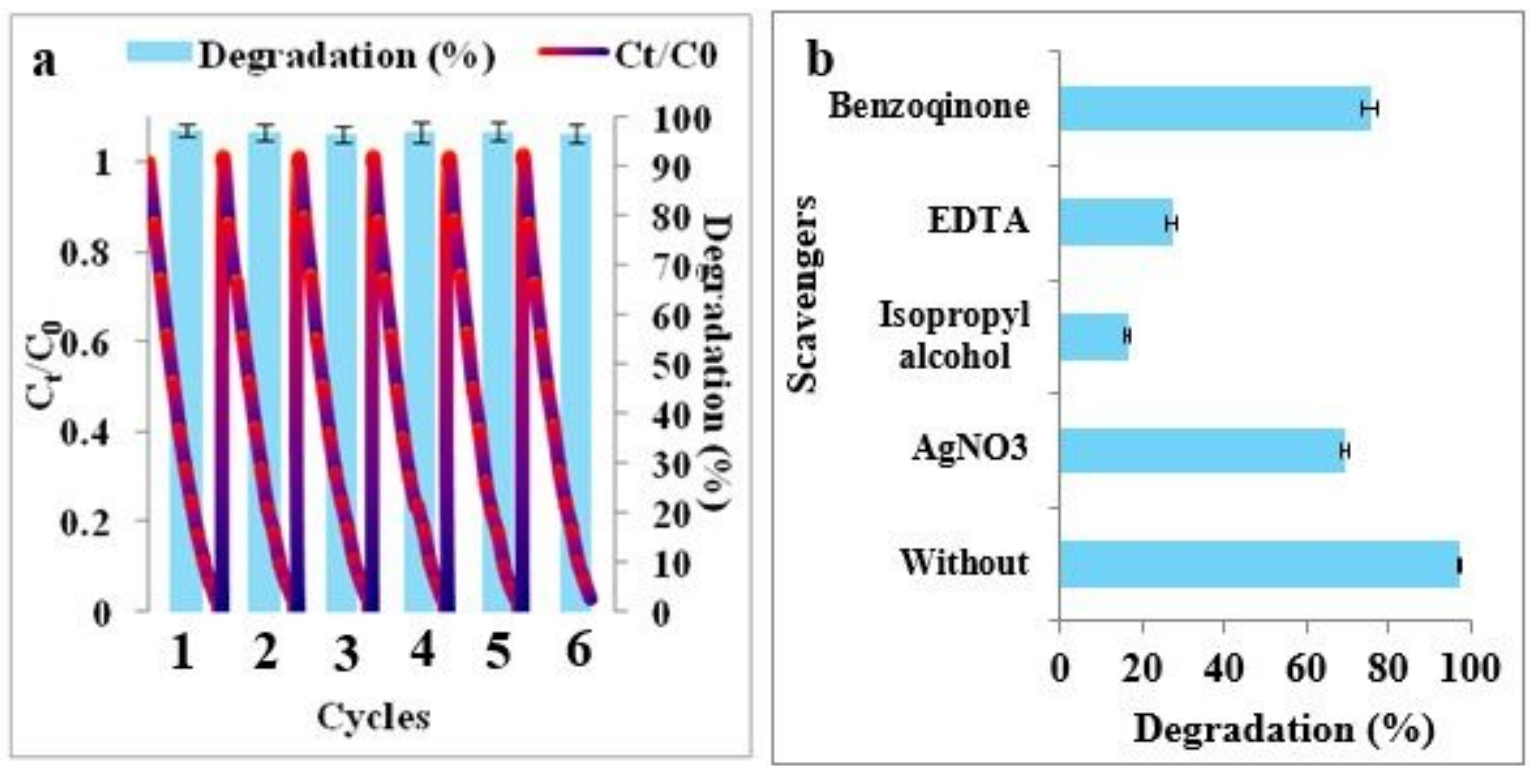

Figure 6

(a) Photocatalytic performance of $\mathrm{CdO} / \mathrm{Al} 2 \mathrm{O} 3$ during six successive cycles and (b) Effect of different scavengers on photocatalytic performance. 

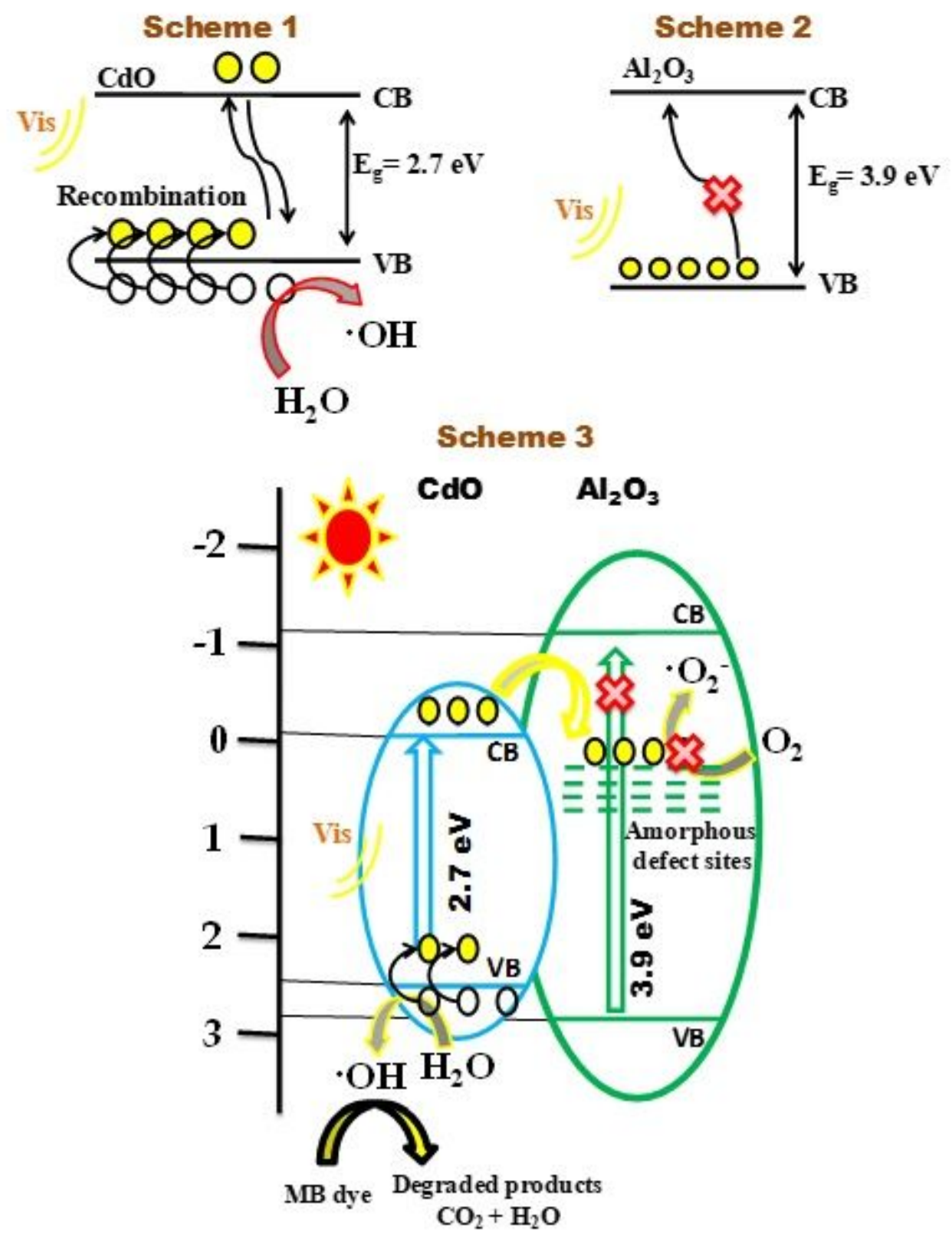

Figure 7

Schematic representation of photocatalytic mechanism of CdO/Al2O3, CdO and Al2O3.. 

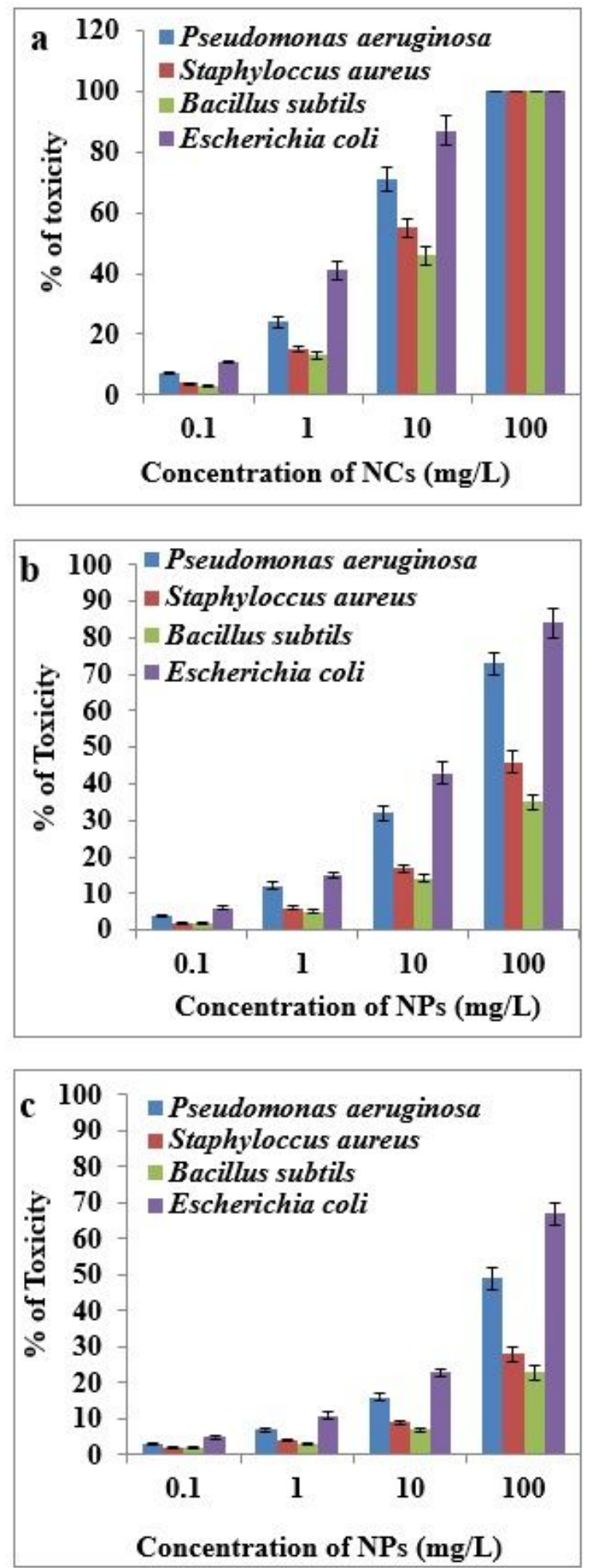

Figure 8

The antimicrobial influence of (a) CdO/Al2O3, (b) CdO and Al2O3 on Staphylococcus aureus, Pseudomonas aeruginosa, Escherichia coli and Bacillus subtilis 